\title{
THE EFFECT OF AVOIDING THE FNB METHODOLOGY IN SECTION 25 DISPUTES
}

\author{
BV Slade \\ B Comm LLB LLM LLD \\ Associate Professor, Department of Public Law, \\ Stellenbosch University
}

\section{SUMMARY}

In First National Bank of SA Ltd t/a Wesbank $v$ Commissioner, South African Revenue Service; First National Bank of SA Ltd t/a Wesbank v Minister of Finance $(F N B)$, the Constitutional Court set out a particular methodology with regard to the adjudication of section 25 disputes. In terms of this methodology, all expropriations in terms of section 25(2) must satisfy the requirements for a valid deprivation in terms of section 25(1). Therefore, the starting point of any constitutional property dispute is section 25(1). However, subsequent case law shows that the methodology proposed by the court is not consistently followed. In cases where the State formally expropriates property, courts customarily ignore the FNB methodology. In this article, it is argued that the avoidance of the $F N B$ methodology in these cases is justifiable.

It has also become clear recently that the courts will on occasion forgo the methodology proposed in FNB even in cases where there was no formal expropriation procedure. In this article, the effect of avoiding the FNB methodology in cases where there was no formal expropriation procedure is considered. It is argued that the avoidance of the FNB methodology in these cases has two interrelated effects. Firstly, parties are free to choose whether to rely on section 25(1) or section 25(2). Litigants are therefore, in theory, free to rely on section 25(2) directly. This makes it possible for litigants to claim compensation in terms of section 25(2), even if no formal expropriation procedure was adopted. Secondly, since litigants can decide whether to rely on section $25(1)$ or section 25(2), the difference between deprivation and expropriation becomes an important initial consideration, although not a simple one. In this article, it is argued that apart from state acquisition, the authority on which the State relies to effect an imposition on property is an important element in distinguishing between deprivation and expropriation.

\section{$1 \quad$ INTRODUCTION}

Section 25 of the Constitution of the Republic of South Africa, 1996 (the Constitution) contains the property clause. Section 25(1) requires that a deprivation of property must be authorised by a law of general application; furthermore, it prohibits the arbitrary deprivation of property. Deprivation of property customarily occurs when the State uses its police power to regulate 
property for public health, welfare and safety reasons. ${ }^{1}$ The regulation therefore imposes some restrictions on an owner's use, enjoyment and exploitation of his or her property. ${ }^{2}$ Section $25(2)$ of the Constitution permits the expropriation of property in cases where it is undertaken in terms of a law of general application and if it will be for a public purpose or in the public interest. An expropriation must also be compensated. An expropriation usually involves the acquisition of property by the State for public purposes, such as building roads. ${ }^{3}$ It is clear that both the regulation of property that causes a deprivation of such property and an expropriation must be authorised by a law of general application.

With the inclusion of a property clause in section 28 of the Constitution of the Republic of South Africa, $1993^{4}$ (the interim Constitution) and in section 25 of the 1996 Constitution, it was assumed that the two-stage approach to Bill-of-Rights litigation would also apply to property disputes. ${ }^{5}$ However, in First National Bank of SA Ltd t/a Wesbank $v$ Commissioner, South African Revenue Service; First National Bank of SA Ltd t/a Wesbank v Minister of Finance, ${ }^{6}$ the Constitutional Court set out a particular methodology in terms of which all constitutional property law disputes should be evaluated (author's own emphasis). In terms of this methodology, all property disputes must start with section 25(1). The court in FNB also set out a series of steps in order to determine whether an infringement of property complies with the constitutional requirements set out in sections 25 and 36 . $^{7}$ However, the methodology proposed by the court in FNB - namely, that all property disputes must begin with section 25(1) - has not been consistently followed in all cases dealing with section 25 of the Constitution. As this article will show, it has become reasonably clear that the FNB methodology will not necessarily be followed in cases where the State has formally expropriated property and the only question is whether the expropriation is for a valid public purpose or in the public interest, or whether the compensation awarded is just and equitable. In this article, it is argued that the avoidance of the FNB methodology in these cases occurs in a principled manner. It is further argued that the avoidance of the FNB methodology in these cases is justifiable.

Van der Walt Constitutional Property Law 3ed (2011) 196, 213; Gildenhuys Onteieningsreg 2ed (2001) 22-24. See also Badenhorst, Pienaar and Mostert Silberberg and Schoeman's The Law of Property 5ed (2006) 540; Van der Walt "Compensation for Excessive or Unfair Regulation: A Comparative Overview of Constitutional Practice relating to Regulatory Takings" 199914 SAPL 279-281, 314-315.

2 Van der Walt Constitutional Property Law 196, 213.

3 See Van der Walt 1999 SAPL 279. See also Badenhorst et al The Law of Property 540. See, for instance, Bartsch Consult (Pty) Ltd $v$ Mayoral Committee of the Maluti-A-Phofung Municipality FSHC 04-02-2010 Case no 4415/2008, where the High Court held that the expropriation of property for purposes of building a road satisfies the public purpose requirement.

200 of 1993

5 Van der Walt The Constitutional Property Clause (1999) 28; Badenhorst et al The Law of Property 528. See also Van der Walt "The Limits of Constitutional Property" 199712 SAPL 275277.

62002 (4) SA 768 (CC). In the first few cases heard by the Constitutional Court, the twostage approach to constitutional litigation was adopted: see S v Zuma 1995 (2) SA 643 (CC) par 21; S v Makwanyane 1995 (3) SA 391 (CC) par 100-104.

7 See Van der Walt Constitutional Property Law 75. 
Furthermore, case law from the Constitutional Court suggests that the FNB methodology may also not necessarily be followed consistently in cases where there has been no formal expropriation. ${ }^{8}$ The court seems to be willing, in some cases at least, to sidestep the FNB methodology and proceed directly to expropriation analysis in terms of section 25(2), even though the interference with property was occasioned by regulatory state action. In this article, the effect of avoiding the FNB methodology in such cases is also considered.

This article is divided into four parts. The first part briefly sets out the FNB methodology and how it affects the application of the property clause. The second part points out that the FNB methodology is not followed in cases where the State has formally expropriated property. The justification for avoiding the FNB methodology in these cases is also highlighted. The third part discusses an interesting Constitutional Court decision in which the court avoided the FNB methodology even though no formal expropriation procedure had been adopted. It is assumed that the avoidance of the FNB methodology in cases where no formal expropriation has occurred will have a tangible impact on how property disputes will be resolved or approached in future. The last part therefore raises questions as to the impact the avoidance of the FNB methodology will have on adjudicating disputes regarding deprivation and expropriation.

\section{SECTION 25 AND THE FNB METHODOLOGY}

It was originally assumed that the two-stage approach to Bill-of-Rights litigation would also apply to adjudicating section 25 disputes. ${ }^{9}$ In terms of the two-stage approach, the first question that is asked is whether there has been an infringement of a right in the Bill of Rights, and if so, the second question is whether that limitation or infringement is justified. ${ }^{10}$ If the twostage approach is followed with regard to section 25 , a litigant would in theory be free to choose whether to rely on section $25(1)$ or section $25(2){ }^{11}$

8 See particularly Arun Property Development (Pty) Ltd v Cape Town City 2015 (2) SA 584 (CC) discussed below.

9 See Slade "Less Invasive Means: The Relationship between Sections 25 and 36 of the Constitution of the Republic of South Africa, 1996" in Hoops, Marais, Mostert, Sluysman and Verstappen (eds) Rethinking Expropriation Law Vol I (2015) 331-348; Van der Walt The Constitutional Property Clause 28; Badenhorst et al The Law of Property 528.

10 See $S$ v Zuma supra par 21; S v Makwanyane supra par 100-104; Ferreira v Levin NO; Vryenhoek v Powell NO 1996 (1) SA 984 (CC) par 44. See also Currie and De Waal The Bill of Rights Handbook 6ed (2013) 23-28.

11 This proposition finds support in the Constitutional Court decision of Harksen $v$ Lane NO 1998 (1) SA 300 (CC), which also dealt with the property clause (s 28) of the interim Constitution. Section 28 also distinguished between deprivation and expropriation. Section 28(2) stated that "[n]o deprivation of any rights in property shall be permitted otherwise than in accordance with a law." Section 28(3) stated that "[w]here any rights in property are expropriated pursuant to a law referred to in ss (2), such expropriation shall be permissible for public purposes only and shall be subject to the payment of agreed compensation ..." In Harksen $v$ Lane NO supra, the applicant challenged the constitutional validity of s 21 of the Insolvency Act 24 of 1936. Relying on s 28 of the interim Constitution, the applicant argued that the operation of $s 21$ of the Insolvency Act in the instant case constituted an expropriation without providing for compensation. The court, having regard to the purpose of the Act as a whole, stated that the operation of s 21 does not "have the effect of a compulsory acquisition or expropriation." This decision shows that the applicant 
If relying on section 25(1), a litigant can seek invalidity of the infringement or limitation on the basis that the interference is not authorised by a law of general application. The litigant can also argue that the infringement amounts to an arbitrary deprivation of property in conflict with section 25(1) that is not justifiable and therefore invalid. If relying on section 25(2), the litigant can attack the validity of an expropriation on the basis that it is not authorised by a law of general application or that it is not undertaken for a public purpose or in the public interest. Alternatively, the litigant can argue that the compensation awarded for the otherwise valid expropriation is not just and equitable as is required by section 25(3).

Although it was originally assumed that the two-stage approach to constitutional litigation would also be applied in cases dealing with section 25(1) and (2) of the Constitution, ${ }^{12}$ the Constitutional Court set out a particular methodology in the FNB decision in terms of which section 25(1) and (2) disputes should be evaluated. In $F N B$, the court stated that expropriation is a subset of deprivation. Therefore, all expropriations in terms of section 25(2) must also satisfy the test for a valid deprivation in terms of section 25(1).

Flowing from the proposed methodology, the court also set out a series of steps in terms of which a property dispute is to be determined. The first enquiry is whether the case involves property and whether there was a deprivation of such property. If the case involves property and the court is satisfied that a deprivation did occur, the question is whether that deprivation complies with section $25(1)$ of the Constitution; in other words, is the deprivation authorised by a law of general application and is the deprivation non-arbitrary? If the deprivation conflicts with section $25(1)$ - if it is arbitrary - the question is whether it is justifiable in terms of section 36 of the Constitution. If the deprivation is justifiable in terms of section 36 , the next question is whether the deprivation also amounts to an expropriation in terms of section 25(2). And if it does amount to an expropriation in terms of section 25(2), does it comply with the requirements for a valid expropriation in terms of this section - that is, is it undertaken in terms of a law of general application (which would already have been answered at an earlier stage) and for a valid public purpose or in the public interest? An expropriation must also be compensated, but it is accepted that compensation is a required result of a valid expropriation and does not validate an expropriation. ${ }^{13}$ If a deprivation amounts to an expropriation and conflicts with section 25(2), the question is whether it can be justified in terms of section 36 . $^{14}$

was free to rely on expropriation (s 28(2)) directly, even though the court accepted that expropriation is a form of deprivation.

12 Van der Walt The Constitutional Property Clause 28; Badenhorst et al The Law of Property 528.

13 Harvey v Umhlatuze Municipality 2011 (1) SA 601 (KZP) par 82. See also Slade in Hoops et al Rethinking Expropriation Law 331.

14 In National Credit Regulator v Opperman 2013 (2) SA 1 (CC) par 75, the Constitutional Court stated that "[m]any of the factors employed under the arbitrariness test to determine sufficiency of reasons yield the same conclusion when considering whether a limitation is reasonable and justifiable under section 36." See further, Slade in Hoops et al Rethinking Expropriation Law 331-347; Van der Walt Constitutional Property Law 77. 
The first few steps, as identified by the court in the FNB decision, are similar to the two-stage approach insofar as it relates to whether an infringement of section 25(1) has occurred. In terms of the FNB methodology, as well as the two-stage approach, the first consideration is whether, based on the specific requirements of section 25(1), an infringement of that section has occurred, and then - if there has been an infringement - the question is whether such infringement is justified. ${ }^{15}$ However, with regard to expropriations in section 25(2), the steps set out by the court in FNB resulting from the methodology signalled a significant methodological shift. In terms of the FNB methodology and the series of steps by which a constitutional property dispute is to be resolved, a claimant can no longer rely on section 25(2) directly; since all expropriations are also deprivations, the expropriation must satisfy the requirements for a valid deprivation first. ${ }^{16}$ This implies that the additional requirement of nonarbitrariness also applies to the question whether an expropriation is justifiable. ${ }^{17}$

In subsequent decisions, some courts have explicitly referred to the FNB steps in considering whether or not a regulatory measure adopted by the State is consistent with section 25(1). For instance, in Shoprite Checkers (Pty) Ltd $v$ MEC for Economic Development, Eastern Cape, ${ }^{18}$ the Constitutional Court specifically referred to the first three steps as set out in FNB in addressing the issue of whether the appellant was deprived of its property. ${ }^{19}$ In other decisions dealing with the question whether a stateimposed regulatory measure is inconsistent with section 25(1), courts do not expressly refer to the FNB steps, but it can be inferred that the first steps in

15 During the first stage of the two-stage approach, consideration is given to whether there was an infringement of $s$ 25(1). This involves determining whether the issue involves property and whether there was an interference with the property in conflict with the requirements set out in s 25(1). In other words, the question is: was there a deprivation that was authorised in terms of a law of general application, and if so, was such deprivation (as duly authorised) arbitrary? If it is found that the interference conflicts with s 25(1), then the question is whether that interference (or limitation) can be justified in terms of $s 36$ of the Constitution. (See Van der Walt Constitutional Property Law 75). In terms of the FNB methodology, the first question that is asked is not whether there was an infringement of s 25(1), but whether the claim (or case) involves property. Once it is established that the case involves property, the question is whether there has been a deprivation of property. If yes, then one asks whether that deprivation complies with $s 25(1)$ - that is, did the deprivation occur in terms of a general application and is the deprivation non-arbitrary? See First National Bank of SA Ltd t/a Wesbank $v$ Commissioner, South African Revenue Service; First National Bank of SA Ltd t/a Wesbank v Minister of Finance supra par 46.

16 The FNB methodology has been lauded (Hopkins and Hofmeyr "New Perspectives on Property" 2003120 SALJ 48-62, especially at 54) and criticised (Roux "Property" in CLoSA (2003) ch 46). For purposes of this article, it is not necessary to go into further details regarding the criticism.

17 See Roux "Property" in CLoSA 28-29. At 4, Roux points out that the outcome of the property clause inquiry will be dependent on the question whether the deprivation of property was arbitrary.

182015 (6) SA 125 (CC) par 6.

19 See also Haffejee NO $v$ eThekwini Municipality 2011 (6) SA 134 (CC) par 26, where the court specifically referred to the FNB methodology in resolving the dispute regarding whether the compensation awarded for a formal expropriation should be determined before or after the expropriation. 
the FNB methodology, which corresponds with the two-stage approach, were followed. ${ }^{20}$

However, there are certain decisions dealing with section 25 of the Constitution where the courts have not followed the FNB methodology. These decisions can be divided into two groups. In the first group are the cases where property is expropriated through a formal expropriation procedure. In these cases, the courts customarily ignore the FNB methodology and proceed directly to consider whether the expropriation complies with section 25(2) of the Constitution. It is argued below that the avoidance of the FNB methodology is justifiable in cases where the State has formally expropriated property.

In the second group, there has been no formal expropriation procedure, but the FNB methodology is not followed. The Constitutional Court decision in Arun Property Development $v$ Cape Town City ${ }^{21}$ (Arun Property Development) indicates a willingness on the part of the court to ignore the FNB methodology, even though there was no expropriation procedure. In this decision, the interference with property rights that ultimately led to the litigation was caused by regulatory state action. In this article, the possible implications of not adhering to the FNB methodology in cases where there has been no formal expropriation decision are investigated. The effect of the application of the property clause, especially insofar as it relates to the justifiability of an expropriation in terms of section 25(2) of the Constitution, is also considered.

\section{AVOIDING THE FNB METHODOLOGY ON A PRINCIPLED BASIS: FORMAL EXPROPRIATION PROCEDURES}

It has been pointed out that the FNB methodology is not followed in all cases dealing with the infringement of property rights. It has become reasonably clear that the courts will not strictly adhere to the FNB methodology in cases where the State has expropriated property by means of a formal expropriation procedure. In others words, courts customarily refrain from following the FNB methodology in cases where a formal expropriation has taken place. A formal expropriation in this case would entail an administrator, empowered by legislation, serving an expropriation notice on the owner indicating the purpose of the expropriation, the date of the

\footnotetext{
20 See Mkontwana $v$ Nelson Mandela Metropolitan Municipality; Bissett $v$ Buffalo City Municipality; Transfer Rights Action Campaign v Member of the Executive Council for Local Government and Housing, Gauteng 2005 (1) SA 530 (CC) par 31-34, where the court considered whether the legislative provisions effected a deprivation of property and whether that deprivation was arbitrary. See also Reflect-All 1025 CC v MEC for Public Transport, Roads and Works, Gauteng Provincial Government 2009 (6) SA 391 (CC) par 26, where the court first considered whether deprivation had occurred, and if so, whether it had been substantively or procedurally arbitrary.

21 Supra.
} 
expropriation and the compensation offered in terms of the Expropriation Act. $^{22}$

In Erf 16 Bryntirion v Minister of Public Works, ${ }^{23}$ the applicant's property was formally expropriated for the purpose of upgrading the security in the Bryntirion estate, which houses the official residence of the President of the Republic of South Africa. The applicant argued that the expropriation was unnecessary, since a less invasive means would be equally effective in realising the purpose of the expropriation. The applicant therefore attacked the expropriation on the basis that it failed the public purpose or public interest requirement contained in section 25(2). Both the High Court and the Supreme Court of Appeal considered only whether the expropriation was justified in terms of section 25(2) in light of the applicant's 'less invasive means' argument. ${ }^{24}$ The Supreme Court of Appeal held that if the expropriation was for a valid public purpose, other less invasive means of realising such purpose were irrelevant. ${ }^{25}$ The courts therefore only considered whether the expropriation was justified in terms of section 25(2) of the Constitution, and did not first consider whether the expropriation complied with the requirements for a valid deprivation in terms of section 25(1) of the Constitution. ${ }^{26}$

In Du Toit $v$ Minister of Transport, ${ }^{27}$ the applicant's property was expropriated in terms of the National Roads Act 54 of 1971 for the purposes of building a road. The applicant argued that the compensation that was offered in terms of the relevant provisions of the Expropriation $\mathrm{Act}^{28}$ was not just and equitable as required by section 25(3). The court immediately proceeded to ask whether the compensation was just and equitable without following the steps in the FNB methodology. ${ }^{29}$

The avoidance of the FNB methodology in cases where there is a formal expropriation speaks to the comment made by Van der Walt shortly after the FNB decision was handed down. Van der Walt stated that "one can only hope that the court will be prepared to forgo its adopted guideline [the FNB

2263 of 1975. See LAWSA X Expropriation par 28-35 for a description of the expropriation procedure in terms of the Expropriation Act 63 of 1975.

23 Erf 16 Bryntirion (Pty) Ltd v Minister of Public Works GPPHC 12-10-2010 Case no 11375/2008; Erf 16 Bryntirion (Pty) Ltd v Minister of Public Works SCA 01-12-2011 Case no 914/2010.

24 Ibid.

25 Erf 16 Bryntirion (Pty) Ltd v Minister of Public Works SCA 01-12-2011 Case no 914/2010 supra par 16. Similarly, the High Court (in Erf 16 Bryntirion (Pty) Ltd v Minister of Public Works GPPHC supra par 54) held that "the fact that there are other ways to achieve the purposes of the expropriation is irrelevant provided that the expropriation is for "public purpose'". (sic). On the less invasive means argument in South African law, see Slade "The Less Invasive Means Argument in Expropriation Law" 2013 TSAR 199-216; Slade in Hoops et al Rethinking Expropriation Law 331-347.

26 See also Bartsch Consult (Pty) Ltd $v$ Mayoral Committee of the Maluti-A-Phofung Municipality supra.

272006 (1) SA 297 (CC).

2863 of 1975.

29 See also Haffejee NO $v$ eThekwini Municipality supra, where the applicant attacked the compensation that was awarded for an expropriation and the Constitutional Court only considered whether the compensation must be established before or after expropriation. On this decision, see Boggenpoel "Compliance with Section 25(2)(b) of the Constitution: When Should Compensation for Expropriation be determined?" 2012129 SALJ 605-620. 
methodology] in suitable cases and go straight to the obvious heart of the matter when expropriation issues are at stake." ${ }^{30}$ The "heart of the matter" in cases where there has been a formal expropriation procedure is arguably only whether that expropriation complies with the legislative provision permitting the expropriation and the requirements set out in section 25(2) of the Constitution. The avoidance of the FNB methodology in (these) suitable cases also seems justifiable. The State is empowered to expropriate property for various purposes in terms of authorising legislation. ${ }^{31}$ The Constitution also permits expropriation in terms of law of general application. If the State has followed the prescriptive process set out in authorising legislation to formally expropriate property, the FNB methodology can justifiably be ignored and - assuming that the correct procedure was adopted - it need only be considered whether the expropriation complies with the specific requirements in section 25(2).

Furthermore, although it may be so that expropriation is a subset of deprivation as per the FNB decision, when the State has decided to expropriate property, it has already decided that the deprivation is a specific kind of deprivation, namely an expropriation. Consequently, the only justification should be found in section 25(2) of the Constitution, which sets out the circumstances in which the State may legitimately expropriate property. ${ }^{32}$ It is arguable that any other reading would render section 25(2) meaningless. If the validity of the expropriation of property through a formal expropriation procedure is subjected to a deprivation analysis, the case will in theory be decided on whether the expropriation is arbitrary in terms of section 25(1). The reason for this is that the inquiry as to whether any infringement with regard to property is justified turns on whether the deprivation is arbitrary as explained in the FNB decision. ${ }^{33}$

If the argument relating to the avoidance of the FNB methodology in cases where there is a formal expropriation procedure is accepted, the FNB methodology should still be applied in cases where the regulation of property by the State leads to a dispute in terms of section 25, or in cases where it is unclear whether the infringement complained of is a deprivation or an expropriation. However, the fairly recent Constitutional Court decision in Arun Property Development illustrates that the FNB methodology may also not be followed in cases where there was no formal expropriation procedure - in other words, in cases where state regulation of property has led to

30 Van der Walt "Striving for a Better Interpretation - A Critical Reflection on the Constitutional Court's Harksen and FNB Decision on the Property Clause" 2004121 SALJ 854 874. This comment relates to the fact that if an expropriation first has to satisfy the requirements for a valid deprivation in terms of $s 25(1)$, then the expropriation will be valid or invalid based on whether the deprivation is arbitrary or not. See fn 15 above.

31 The power to expropriate is a public power that only the State may exercise: Pretoria City Council v Modimola 1966 (3) SA 250 (A) 259. However, the State must exercise this power to expropriate on the basis of authorising legislation and in compliance with the constitutional provisions. See Gildenhuys Onteieningsreg 9-10.

32 In this regard, Dugard and Seme "Property Rights in Court: An Examination of Judicial Attempts to Settle Section 25's Balancing Act re Restitution and Expropriation" 201834 SAJHR 33-44, convincingly argue that "expropriation is a distinct sub-set of deprivation requiring a separate investigation".

33 See Van der Walt Constitutional Property Law 77-78; Roux CLoSA 2, 23; Van der Walt "Section 25 Vortices (Part 1)" 2016 TSAR 412 412-413. 
litigation. This decision is discussed briefly below to show the possible ultimate implications that the avoidance of the methodology may have on constitutional property law.

\section{AVOIDING THE FNB METHODOLOGY IN CASES WHERE THERE IS NO FORMAL EXPROPRIATION PROCEDURE: ARUN PROPERTY DEVELOPMENT}

In Arun Property Development, the issue was whether the applicant was entitled to compensation for property that vested in the city in terms of an approved subdivision plan that was in excess of the normal need. ${ }^{34}$ In the very first paragraph, the Constitutional Court stated that this case raises a "significant constitutional issue connected to the expropriation of land and compensation., ${ }^{35}$ The court therefore placed the issue to be decided in the context of expropriation. In its decision, the court, in one place, stated that it would prefer an interpretation of the relevant provision that was at peace with section 25(2) ${ }^{36}$ At another place, the court stated that the city's arguments were no bar to the applicant claiming compensation for the expropriation of its land. ${ }^{37}$ However, it is clear from the judgment that in this particular case, there was no formal expropriation procedure in terms of which additional (or excess) property was expropriated by the relevant authority.

In this decision, the City of Cape Town approved a subdivision plan in terms of the Cape Land Use Planning Ordinance 15 of 1985 (LUPO). The purpose of LUPO is to regulate orderly township development in the jurisdiction of the City of Cape Town. In terms of the subdivision plan, a developer has to donate land to the city based on the normal need to provide the development with roads and open spaces. The applicant argued that land in excess of those of the normal need vested in the city, and that it was entitled to compensation. The court accepted that it is legitimate to expect the developer to part with land that is based on the normal need, without compensation. In constitutional property law, this donation is considered to be a development contribution (or exaction in United States law). ${ }^{38}$ Development contributions, as part of the process in terms of which developments are approved, are regulatory in nature and the validity of such contributions must therefore be judged against the requirements for a valid deprivation in section 25(1) of the Constitution. ${ }^{39}$ Despite the fact that the land vested in the city in terms of a regulatory scheme, the court did not consider whether the vesting met the requirements for a valid deprivation in terms of section 25(1), as prescribed by the FNB methodology.

34 For a discussion of this decision, see Slade "Compensation for What? An Analysis of the Outcome in Arun Property Development (Pty) Ltd v Cape Town City" 201619 PER 1-25.

Arun Property Development supra par 1.

36 Par 41.

Par 62.

38 On exactions in US law, see Nollan v California Coastal Commission 483 US 825 (1987); Dolan v City of Tigard 512 US 374 (1992); Singer Introduction to Property 2ed (2005) 736-737. On development contributions in South African law, see Van der Walt Constitutional Property Law 290-292; Slade 2016 PER 12-17.

39 See Slade 2016 PER 12-17; Van der Walt Constitutional Property Law 290-292. 


\section{THE EFFECT OF AVOIDING THE FNB METHODOLOGY IN AN UNPRINCIPLED MANNER}

It has been pointed out that the FNB methodology is not customarily followed in cases where a formal expropriation has occurred. The justification for avoiding the FNB methodology in such cases has also been highlighted. However, the discussion of Arun Property Development above indicates that the Constitutional Court will not necessarily apply the FNB methodology to section 25 disputes, even in cases where property has not been expropriated through a formal expropriation procedure. ${ }^{40}$

The avoidance of the FNB methodology in cases dealing with an infringement on property rights (other than the cases where there is a formal expropriation) may have two interrelated effects on constitutional property law as well as on the manner in which these cases will be presented to the courts in future.

Firstly, litigants are apparently free to choose to bring their case either in terms of section 25(1) or section 25(2). A litigant will therefore be free to seek compensation in terms of section 25(2), even in the absence of a formal expropriation procedure. This was not possible in terms of the FNB methodology since in those terms all constitutional property disputes have to start with section 25(1). However, Arun Property Development shows that the court will consider whether compensation is due to an aggrieved party even if the litigation is as a result of regulatory action, and not an expropriation, and even if there is no agreement between the parties that the deprivation amounts to an expropriation (as in Agri South Africa v Minister for Minerals and Energy). ${ }^{41}$

Secondly, since litigants are free to choose whether to bring the case in terms of section 25(1) or section 25(2), the distinction between deprivation and expropriation becomes more important. In terms of the FNB judgment, all expropriations are deprivations. Therefore, only after it has been established that the infringement constitutes a deprivation that is not in conflict with section 25(1) is it asked whether the deprivation also amounts to an expropriation that complies with the requirements in section 25(2). As a result, the difference between a deprivation and an expropriation only arises later if the analysis passes through all the steps. ${ }^{42}$ It is possible that the inquiry ends at an earlier stage - for instance, if it is found that the deprivation is arbitrary and not justifiable in terms of section 36 of the Constitution, and is therefore invalid. If the enquiry ends at this earlier stage, the question whether the deprivation also amounts to an expropriation does not arise. However, if the FNB methodology is not followed, or if the twostage approach to constitutional litigation is adopted, the difference between deprivation and expropriation may be an important initial consideration, since litigants would have the freedom to choose whether to rely on section 25(1)

\footnotetext{
See the discussion of Arun Property Development supra above.

2013 (4) SA 1 (CC).

42 See Van der Walt 2004 SALJ 867; Marais "When does State Interference with Property (Now) Amount to Expropriation? An analysis of the Agri SA Court's State Acquisition Requirement (Part II)" 201518 PER 30333060.
} 
in seeking invalidation, or on section 25(2) to seek invalidation or compensation.

In Agri South Africa $v$ Minister for Minerals and Energy, ${ }^{43}$ the Constitutional Court suggested that the difference between deprivation and expropriation is that expropriation involves state acquisition while deprivation does not. State acquisition may therefore be regarded as the distinguishing factor between deprivation and expropriation. However, the difference between deprivation and expropriation is not that simple. ${ }^{44}$ There are examples, such as the imposition of tax, where the State's use of its regulatory powers leads to the acquisition of property. The acquisition of property in these instances is, however, not regarded as an expropriation. ${ }^{45}$

If the difference between deprivation and expropriation becomes more important, the effect of state action on property should not be the main (or only) criteria used to distinguish between deprivation and expropriation. ${ }^{46}$ Thus, if the effect of the imposition is to vest property in the State, it does not mean that the imposition is automatically an expropriation. With reference to Harksen $v$ Lane NO and Australian law, Marais suggests that one should also consider the purpose of the source that effects the imposition on property. ${ }^{47}$ Since the State is only entitled to regulate and expropriate property in terms of authorising legislation, the authority to perform an action must be an important consideration to determine whether a deprivation or an expropriation has occurred. ${ }^{48}$ Therefore, if courts are willing to forgo the FNB methodology, and if the difference between deprivation and expropriation becomes an important initial consideration, state acquisition should only be one of the distinguishing features between deprivation and expropriation. Another very important consideration is the authority on which the State relies to effect an imposition on property. It has been argued that an expropriation must be specifically authorised in legislation. ${ }^{49}$ An expropriation would not be valid if not specifically authorised in legislation. In the absence of such legislation, the validity of any interference with property must first be assessed in terms of section 25(1). Only in cases where the property has been formally expropriated on the basis of legislation will avoiding the FNB methodology be justified.

43 Supra par 48.

44 Van der Walt Constitutional Property Law 197-200, 336-347; Badenhorst et al The Law of Property 540-544.

45 Van der Walt Constitutional Property Law 347. Further examples include the confiscation and forfeiture of property in terms of legislation (Director of Public Prosecutions: Cape of Good Hope v Bathgate 2000 (2) SA 535 (C); National Director of Public Prosecutions v Prophet 2003 (6) SA 154 (C); Van der Walt Constitutional Property Law 314-333) and development contributions or exactions (Van der Walt Constitutional Property Law 290-291; Slade 2016 PER 12-17; Singer Introduction to Property 736-737).

46 Van der Walt Constitutional Property Law 200; Marais 2015 PER 3045-3052, 3062-3063.

47 Marais 2015 PER 3045-3052, 3062-3063.

48 See Van der Walt Constitutional Property Law 209-210.

49 See Slade "The 'Law of General Application' Requirement in Expropriation Law and the Impact of the Expropriation Bill of 2015" 2017 De Jure 346-362. 